\title{
Mechanisms behind COX-1 and COX-2 inhibition of tumor growth in vivo
}

\author{
HANS AXELSSON, CHRISTINA LÖNNROTH, MARIANNE ANDERSSON and KENT LUNDHOLM \\ Department of Surgery, Institute of Clinical Sciences, Sahlgrenska Academy, \\ Sahlgrenska University Hospital, Gothenburg, Sweden
}

Received June 9, 2010; Accepted July 19, 2010

DOI: 10.3892/ijo_00000766

\begin{abstract}
Non-steroidal anti-inflammatory drugs (NSAIDs) attenuate tumor net growth in clinical and experimental cancer. Evaluations in cell culture experiments have implied involvement of growth factor and G-protein related signaling pathways to explain decreased proliferation, angiogenesis, increased cell adhesion and apoptosis. Sparse information is however available from studies on growing tumors in vivo. The aim of the present study was to map alterations in selected signal proteins in relation to heterogeneous tissue expression of COX-2 in tumors during COX inhibition. MCG 101 cells were exposed to indomethacin treatment both in vivo and in vitro to reduce $\mathrm{PGE}_{2}$ production. Tumor tissue specimens were taken for immunohistochemical analyses and qPCR determinations. Protein markers were selected to reflect cell proliferation and cell cycling, angiogenesis and metastasis in relationship to COX-2 staining in tumor tissue. Indomethacin did not change overall COX-2 staining in tumor tissue, but altered its distribution towards increased staining in cell nuclei/ nucleoli and decreased COX-2 staining heterogeneity in tumor tissue. P53 staining was decreased, while PCNA and TGFß3 staining were increased by indomethacin in tumor areas with high presence of COX-2, which correlated to staining of BAX, TUNEL, Bcl-2, c-jun, p21, p27, p53 and NM23. Net tumor growth was predicted by EGF-R, p21 and p27 proteins in tumor tissue during indomethacin treatment (multivariate analysis). RNA transcript analyses showed decreased EGF-R and KRas expression in vivo, following indomethacin treatment, which also included KRas, PI3K, JAK1, STAT3 and c-jun, mRNAs in cultured tumor cells. In conclusion, our results extend earlier studies on cell culture experiments and demonstrate that EGF-R and downstream KRas pathways communicate effects of increased prostaglandin activity in tumor tissue in vivo.
\end{abstract}

Correspondence to: Professor Kent Lundholm, Department of Surgery, Sahlgrenska University Hospital, SE 41345 Göteborg, Sweden

E-mail: kent.lundholm@surgery.gu.se

Key words: COX-1, COX-2, prostanoids, EGF-R

\section{Introduction}

It is well known that non-steroidal anti-inflammatory drugs (NSAIDs) attenuate tumor net growth, probably due to attenuated local and systemic inflammation due to reduced prostaglandin production in tumor and host tissues (1-6). This leads to decreased host appearance of acute phase proteins in both tumor-bearing animals and cancer patients (2,7-9). Such overall effects are related to reduced tumor growth $(3,4,7)$, improved appetite and attenuation of cachexia with subsequent prolongation of survival in experimental models $(3,4,10,11)$. Similar overall improvements have been observed in cancer patients on systemic anti-inflammatory treatment (9,12-15). Thus, cyclooxygenase inhibition evokes both local tumor and host systemic effects characterized by decreased cell proliferation and increased tumor cell apoptosis related to attenuated angiogenesis demonstrated in vivo by intravital chamber technology (16-20). Such effects appear to be related to complex interactions between growth factors and cytokines on tumor cell membrane receptors with subsequent downstream signaling pathways (21-32), but represent probably also net activities in cross-talk between host stroma and tumor cells with prostanoids being important factors, particularly $\mathrm{PGE}_{2}$, with signaling through subtype $\mathrm{EP}_{1-4}$ receptors in host and tumor cells $(16,33)$. However, most information on specific pathways across tumor cell membranes originates from cell culture experiments (21-31), and less confirmed information is available from tissue and organ perspectives (34-36). Therefore, we have evaluated the relationship between net tumor growth and various proteins with recognized importance for tumor progression, in order to initiate mapping of mechanisms behind reduced tumor growth by COX inhibition in vivo in a tumor model highly sensitive to $\mathrm{PGE}_{2}$ $(3,7,10,11)$.

\section{Materials and methods}

Tumor model. A methylcholanthrene-induced sarcoma (MCG-101) was used in the present study (37). This tumor produces increased systemic levels of prostaglandin $\mathrm{E}_{2}$, and COX-1/COX-2 inhibition by indomethacin reduced tumor growth, improved appetite and nutritional state and prolonged survival by attenuation of systemic concentrations of $\mathrm{PGE}_{2}$ down to normal levels in tumor-bearing hosts $(3,10,11)$. The MCG-101 tumor has been grown continuously in vivo at our 
Table I. List of antibodies and working conditions.

\begin{tabular}{|c|c|c|c|c|c|}
\hline Antibody & Isotype & Supplier & Product code & $\begin{array}{c}\text { Concentration } \\
\mu \mathrm{g} / \mathrm{ml}\end{array}$ & $\begin{array}{l}\text { Antigen } \\
\text { retrieval }\end{array}$ \\
\hline Goat anti-human Cox-2 & \multirow{14}{*}{$\operatorname{IgG}_{2 \mathrm{a}}$} & Santa Cruz & sc-1746 & 1 & $\mathrm{E}^{\mathrm{a}}$ \\
\hline Rabbit anti-human p53 & & Santa Cruz & sc- 6243 & 2 & $\mathrm{MW}^{\mathrm{b}}$ \\
\hline Rabbit anti-human EGFR & & Santa Cruz & sc-03 & 0.25 & $\mathrm{E}^{\mathrm{a}}$ \\
\hline Rabbit anti-human Bax & & Santa Cruz & sc-493 & 0.25 & $\mathrm{E}^{\mathrm{a}}$ \\
\hline Rabbit anti-human Bcl-2 & & Santa Cruz & sc-492 & 0.25 & $\mathrm{E}^{\mathrm{a}}$ \\
\hline Rabbit anti-human c-Jun & & Santa Cruz & sc-1694 & 2 & $\mathrm{MW}^{\mathrm{b}}$ \\
\hline Rabbit anti-human p21 & & Santa Cruz & sc-397 & 4 & $\mathrm{MW}^{\mathrm{b}}$ \\
\hline Rabbit anti-human p27 & & Santa Cruz & sc-528 & 2 & $\mathrm{MW}^{\mathrm{b}}$ \\
\hline Mouse anti-human PCNA & & Santa Cruz & sc-56 & 1 & $\mathrm{MW}^{\mathrm{b}}$ \\
\hline Goat anti-mouse TRT & & Santa Cruz & sc-9652 & 4 & $\mathrm{MW}^{\mathrm{b}}$ \\
\hline Rabbit anti-human TGF B3 & & Santa Cruz & sc-82 & 0.25 & $\mathrm{E}^{\mathrm{a}}$ \\
\hline Rabbit anti-human nm 23-H1 & & Santa Cruz & sc-343 & 0.5 & $\mathrm{E}^{\mathrm{a}}$ \\
\hline \multicolumn{5}{|l|}{ TUNEL apoptosis detection } & \\
\hline In situ cell death detection kit, AP & & Roche Applied Science & 11684809910 & $\mathrm{NA}^{\mathrm{c}}$ & $\mathrm{NA}^{\mathrm{c}}$ \\
\hline
\end{tabular}

laboratory since 1972. It was originally induced chemically as a sarcoma, but more recent evaluations demonstrated that it had few if any characteristics of a sarcoma. It should therefore rather be classified as a low or undifferentiated rapidly growing solid tumor. It has a reproducible and exponential growth pattern with a doubling time $\sim 55-60 \mathrm{~h}$ in vivo (38). It leads to $100 \%$ tumor take and does not give rise to visible metastases within the time period it kills the host in a state of severe anorexia and cachexia, usually after 12-14 days of tumor growth (37).

Animal groups. The present investigation was carried out by two kind of experiments. In total 34, adult, age-matched, weight-stable (20-24 g), female, wild-type C57 black mice were used; 16 in the first experiment where tumors were inoculated in intravital chambers for early detection and isolation (17); 18 mice were used in the second experiment with conventional s.c. tumor inoculation as described $(3,37)$. Half the number of tumor-bearing animals was treated with indomethacin in drinking water as described below (study groups), and remaining tumor-bearing animals served as controls. All animals were housed in plastic cages in a temperature controlled room $\left(24^{\circ} \mathrm{C}\right)$ with a $12 \mathrm{~h}$ light/dark schedule. They were provided free access to water and standard laboratory rodent chow. The experiments were performed according to the institutional guidelines on ethics.

Isolated tumor cells $\left(10^{5}\right)$ or tumor tissue $\left(3 \mathrm{~mm}^{3}\right)$ were implanted under light i.p. anesthesia (Ketalar $\left.{ }^{\circledR}, \operatorname{Rompun}^{\circledR}\right)$. The mice were either sacrificed after 5 days (intravital chambers) or 10 days (conventional s.c.) of tumor growth as indicated in tables and figures. Final tumors were dissected free for weighing. Treatment groups received indomethacin (Confortid, $5 \mathrm{mg} / \mathrm{ml}$, Dumex-Alpharma) provided in the drinking water corresponding to $6 \mu \mathrm{g} / \mathrm{ml}$ drinking water $(3,10,11,18)$. The appropriate dilution of indomethacin in the drinking water was calculated based on daily normal water consumptions of the mice (3-4 ml water/mouse/day) (3). This corresponds to indomethacin of $1 \mu \mathrm{g} / \mathrm{g}$ bw/day. Controls received ordinary drinking water. Micro-tumors growing in intravital chambers were harvested for analyses as described (16).

Immunohistochemistry. For IHC, tumor tissue was kept refrigerated in $4 \%$ buffered formaldehyde solution for three days, washed and kept in $70 \%$ ethanol until dehydration and paraffin embedding. Formalin-fixed and paraffin embedded tissue sections $(4 \mu \mathrm{m})$ were deparaffinized and rehydrated according to standard procedures and rinsed twice in $5 \mathrm{mM}$ Tris-buffered saline (TBS), $\mathrm{pH}$ 7.8. All further washes were done in TBS throughout the experiment. Sections were either microwave-irradiated or enzyme treated. Specification of antigen retrieval (AR), antibodies, host species, final concentrations and suppliers are given in Table I. Sections were mounted with Shandon coverplates. Non-specific protein binding was initially blocked with TBS, containing 5\% fatfree dry milk, which was also used for dilution of antibodies and normal IgG. Further non-specific binding was also blocked with either normal goat IgG (sc-2028) or rabbit IgG (sc-2027) (Santa Cruz) or normal mouse $\operatorname{IgG}_{2 \mathrm{a}}$ (X0943, Dako Cytomation), to match the species of secondary antibodies. This was followed by Dako Biotin Blocking System, X0590. Primary antibodies and corresponding concentrations of normal $\mathrm{IgG}$ for negative controls, were incubated overnight at $+4^{\circ} \mathrm{C}$. Secondary biotinylated antibodies used, were goat anti-rabbit (sc-2040, 1/400) or goat anti-mouse (sc-2039, 1/200) (Santa Cruz) or rabbit anti-goat (Dako E0466, 1/500). Following rinses, Streptavidin-alkaline phosphatase (RPN 
Table II. Genes downstream to the EGF-R as illustrated in Fig. 5A.

\begin{tabular}{lccc}
\hline Gene & Accession no. & $\begin{array}{c}\text { QuantiTect } \\
\text { Primer assay code }\end{array}$ & $\begin{array}{c}\text { Fragment length } \\
\text { base pair }\end{array}$ \\
\hline Mm EGF-R & NM_007912 & QT00101584 & 68 \\
NM_207655 & QT00158438 & 72 \\
Mm JAK1 & NM_146145 & QT2 & 144 \\
Mm STAT1 & NM_009283 & QT01149519 & 99 \\
Mm STAT3 & NM_011486 & QT00148750 & \\
& NM_213659 & & 144 \\
Mm ELK1 & NM_007922 & QT00172893 & 89 \\
MmPI3K & NM_008839 & QT00149709 & 75 \\
Mm Jun & NM_010591 & QT00296541 & 140 \\
Mm K-Ras & NM_021284 & QT00173033 & \\
\hline
\end{tabular}

1234, 1/150, Amersham Biosciences) was added. For colour development, Dako Fast Red Substrate System (K699) was used followed by counter staining in hematoxylin. Sections were mounted in Mount Quick Aqueous (Histolab Products $\mathrm{AB}$, Sweden). In situ cell death detection, was run according to kit instructions, as earlier described (Table I) (10).

Image analysis of proteins. Immunohistochemically stained slides were studied in microscope and digital photos were taken for computerized image analysis; 2-8 different areas of each tumor sample were studied in greater magnification. Fields for evaluation was chosen around areas with either high or low presence of COX-2 protein in tumor tissue. The number of evaluated vision fields did not differ between control and indomethacin treated animals. Evaluated areas were exactly the same for all analyzed proteins in each tissue section in order to avoid any selection bias. Computer based image analysis (Easy Image Analysis 2000, Tekno Optik AB) were performed for quantification of expressed proteins as described (16). Specific protein staining area was the fraction (\%) of each studied tumor area specifically stained for a particular protein being a measure of the protein content in that particular tissue area. Specific protein area was measured in all evaluated tumor areas for all analyzed proteins. COX-2 was quantified by both the manual method, which included estimates of area and intensity, and the alternative computerized image analysis technique. The two methods for quantitative estimates gave results with high correlation assessed in separate evaluations by independent investigators. COX-2 was used as the test protein in this respect and the correlation between the manual and the computerized methods was high (Rho=0.88; $\mathrm{p}<0.0001)$. Our present approach for measurements of correlations is also representative for relationships between proteins in the presence or absence of COX-2 protein.

RNA extraction and cDNA synthesis. Tissue samples were either snap-frozen in liquid nitrogen and kept at $-80^{\circ} \mathrm{C}$ or put in
RNAlater (Ambion) for $24 \mathrm{~h}$ at $4^{\circ} \mathrm{C}$ and then kept at $-20^{\circ} \mathrm{C}$ until analysis of RNA expression. Total RNA was either isolated by the RNAzol method (code CS-101, Cinna/Biotecx Laboratories, Inc., TX, USA) or extracted with RNeasy Micro kit (cat. no. 74004, Qiagen) following the protocol for 'Total RNA isolation from microdissected cryosections' (intravital chamber tumors). One microgram or 500 nanogram of total RNA from the two experiments was reverse transcribed to cDNA with Advantage ${ }^{\circledR}$ RT-for-PCR kit (ClonTech cat. no. 639506, BD BioScience) according to kit protocol. Each sample was diluted to a final volume of $100 \mu 1$. Reactions were run in parallel, with the reverse transcriptase being omitted in the control for DNA contamination. RNA from cultured cells was extracted with RNeasy Midi kit (Qiagen) according to the kit instructions. Synthesis of cDNA from MCG-101 cultured cells was performed as described above, with $1 \mu \mathrm{g}$ of total RNA reversed transcribed. RNA quality and concentrations were checked after extraction in Bioanalyzer from Agilent Technology before cDNA synthesis.

Quantitative real-time PCR. Real-time PCR was performed in a LightCycler 1.5 with QuantiTect SYBR Green PCR kit and QuantiTect Primer assays (Table II). PCR conditions were: $15 \mathrm{~min}, 95^{\circ} \mathrm{C}$ initial activation; 3-step cycling with $15 \mathrm{sec}$, $94^{\circ} \mathrm{C}$ denaturation; $20 \mathrm{sec}, 55^{\circ} \mathrm{C}$ annealing; $20 \mathrm{sec}, 72^{\circ} \mathrm{C}$ extension. Number of cycles were 45-50. cDNA fractions $(2 \mu 1)$ were used for each amplification. All samples were analyzed in duplicate and compared to the expression of glyceraldehyde-3-phosphate dehydrogenase (GAPDH, Control Amplimer Set, 639003, BD Biosciences), which was used as housekeeping gene and amplified with LightCycler Fast Start DNA Master Plus SYBR Green 1 (code 03515885001, Roche). PCR conditions for GAPDH: $10 \mathrm{~min}, 95^{\circ} \mathrm{C}$ initial activation; 3-step cycling with $10 \mathrm{sec}, 95^{\circ} \mathrm{C}$ denaturation; $6 \mathrm{sec}, 60^{\circ} \mathrm{C}$ annealing; $18 \mathrm{sec}, 72^{\circ} \mathrm{C}$ elongation for 40 cycles. Quantitative results were derived using the relative standard curve method, where standard specimen was cDNA from MCG tumor tissue of an untreated control mouse. All PCR products had expected size, analyzed with Agilent 2100 Bioanalyzer in DNA 1000 Chip and all reactions were confirmed using both positive and negative controls (one dilution of standard curve cDNA and water substituted for cDNA, respectively).

Cell culture. MCG-101 cell line, established from the mouse MCG-101 tumor according to standard procedures, was used in vitro. Cells were maintained in McCoy's 5A medium (Fisher Scientific, Sweden) supplemented with $10 \%$ fetal calf serum (FCS), referred to as complete medium, with a split ratio of $1 / 5$ once weekly and with a medium change in between (McCoy's $5 \mathrm{~A}+2 \% \mathrm{FCS}$ ). Standard concentrations of penicillin (100 IU/ $\mathrm{ml}) /$ streptomycin $(100 \mu \mathrm{g} / \mathrm{ml})$ and L-glutamin $(292 \mu \mathrm{g} / \mathrm{ml})$ were used. Tissue culture flasks, $25 \mathrm{~cm}^{2}$, were used. Indomethacin (Confortid $^{\circledR}, 8.4 \mu \mathrm{M}$ ) was added at start of cell cultures grown in complete medium or replaced with saline in controls. Decreased $\mathrm{PGE}_{2}$ production in conditioned media was measured as a control of drug efficiency as earlier described (18).

Statistics. Results in tables and figures are presented as mean \pm SEM. Statistical comparisons between different groups 
Table III. Protein staining area (\%) of individual proteins and DNA strand breaks (TUNEL) in tumor tissue from indomethacintreated and control mice in randomly selected areas.

\begin{tabular}{lcccccl}
\hline & $\mathrm{n}_{1}$ & $\mathrm{n}_{2}$ & Indomethacin & Control & p-value & \\
\hline COX-2 & 18 & 92 & $2.14 \pm 0.69$ & $1.64 \pm 0.46$ & NS & Inflammation \\
p53 & 12 & 73 & $3.74 \pm 0.84$ & $5.91 \pm 0.97$ & $<0.01$ & Angiogenesis, apoptosis, cell cycle and cell proliferation \\
EGF-R & 13 & 62 & $9.75 \pm 2.23$ & $12.76 \pm 2.39$ & NS & Angiogenesis, apoptosis, cell cycle and cell proliferation \\
BAX & 12 & 62 & $16.3 \pm 4.3$ & $28.7 \pm 4.5$ & NS & Apoptosis \\
TUNEL & 13 & 68 & $17.2 \pm 2.6$ & $23.9 \pm 3.0$ & NS & Apoptosis \\
Bcl-2 & 13 & 66 & $4.37 \pm 1.71$ & $2.51 \pm 0.56$ & NS & Apoptosis \\
c-jun & 18 & 97 & $7.33 \pm 1.46$ & $4.35 \pm 0.75$ & NS & Apoptosis, cell cycle and cell proliferation \\
TRT & 10 & 27 & $0.30 \pm 0.19$ & $0.18 \pm 0.08$ & NS & Cell cycle and cell proliferation \\
p21 & 18 & 97 & $0.07 \pm 0.02$ & $0.06 \pm 0.02$ & NS & Cell cycle and cell proliferation \\
p27 & 12 & 63 & $2.21 \pm 0.47$ & $5.29 \pm 1.52$ & NS & Cell cycle and cell proliferation \\
PCNA & 18 & 95 & $14.2 \pm 1.8$ & $6.75 \pm 0.88$ & $<0.001$ & Cell cycle and cell proliferation \\
TGFB3 & 12 & 61 & $0.15 \pm 0.09$ & $0.09 \pm 0.02$ & $<0.03$ & Cell cycle and cell proliferation \\
NM23 & 18 & 90 & $19.1 \pm 3.4$ & $21.7 \pm 3.2$ & NS & Metastasis/Invasion \\
\hline
\end{tabular}

Mean \pm SEM; Mann-Whitney U-test; $\mathrm{n}_{1}$, number of animals sacrificed 10 days after tumor implantation; $\mathrm{n}_{2}$, number of evaluated vision fields of tumor tissue; NS, not significant.

A

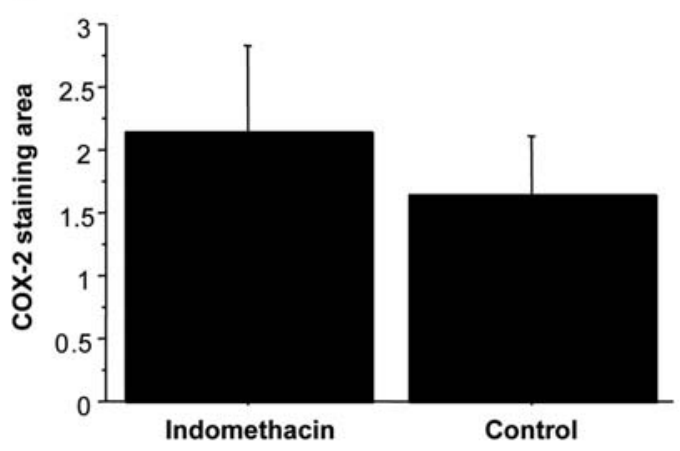

B

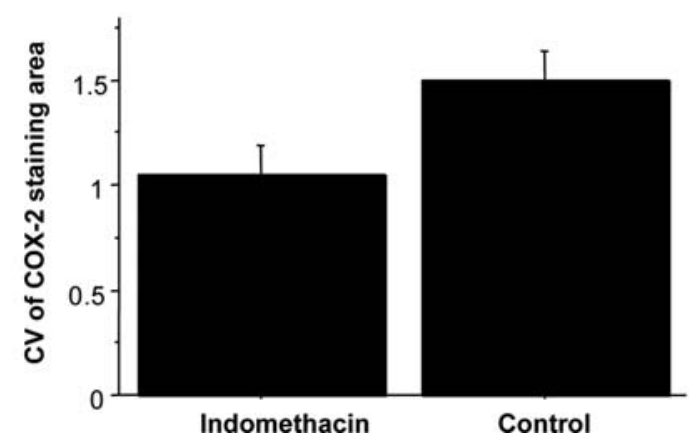

Figure 1. (A) COX-2 staining areas in tumor tissue from indomethacin treated (10 days) and control mice (Mean \pm SEM). (B) Coefficient of variation of COX-2 staining in tumor tissue from indomethacin treated (10 days) and control mice $($ Mean \pm SEM, $\mathrm{p}<0.05)$.

were, however, performed by non-parametric statistics (Mann Whitney). Spearman Rank correlation coefficient was used in correlation analyses. Coefficient of variance (CV) was used as a measure of variability $(\mathrm{CV}=\mathrm{SD} / \mathrm{mv} ; \mathrm{SD}=$
Standard deviation, $\mathrm{mv}=$ mean value). $\mathrm{P}<0.05$ was regarded statistically significant in two-tailed tests. Multivariate analyses were performed by stepwise forward and multiple linear regression standard methods and frequency analysis was performed by $\chi^{2}$-testing.

\section{Results}

The overall presence of COX-2 in tumor tissue was not significantly affected by indomethacin treatment (Fig. 1A; Table III), but the variation of COX-2 protein staining in such tumors was significantly reduced following indomethacin treatment $(\mathrm{p}<0.05)$ (Fig. 1B). This variation was calculated from information in immunohistological sections from tumors across areas with pronounced and low heterogeneity (high, low coefficient of variation) (Fig. 2). There was also a significantly positive correlation between the coefficient of variation of COX-2 staining area and tumor weight (Fig. 3). p53 was significantly decreased in tumor tissue, while PCNA and TGFß3 were significantly increased following indomethacin treatment (Table III). Staining areas of c-jun and p27 correlated to COX-2 staining in indomethacin treated animals, but not in controls (Table IV), while staining areas of BAX, TUNEL and p53 were positively correlated to COX-2 staining in tumor tissue from control animals, but not in indomethacin treated tumors. Staining areas of Bcl-2, NM23 and p21 correlated to COX-2 staining in tumors from both indomethacin treated and untreated controls (Table IV). EGF-R staining in tumor tissue was positively correlated to tumor growth, while c-jun, NM23 and PCNA correlated negatively in univariate analysis (Table V). Aspects beyond correlations among specific protein staining were altered distributions of COX 2 and PCNA proteins in tumor cells from indomethacin treated tumors. COX-2 protein appeared present more in nuclei and nucleoli with less cytoplasmic granulation following 
a.
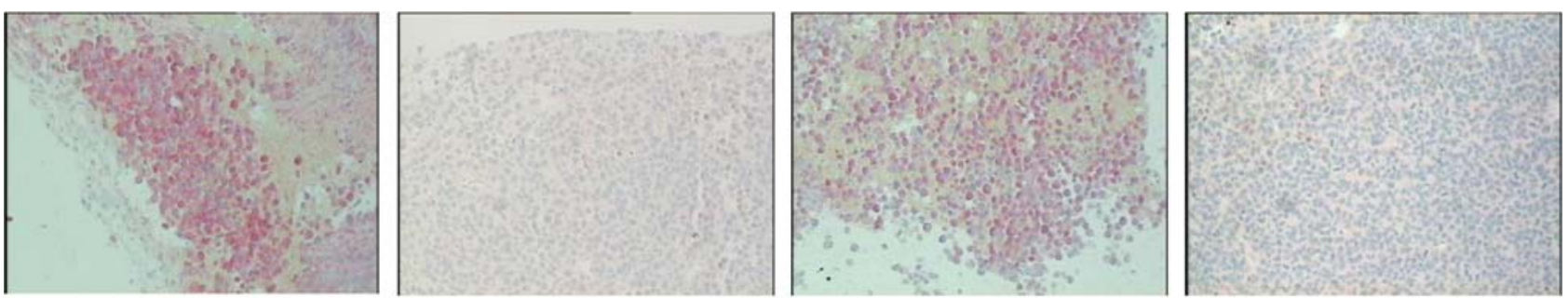

b.
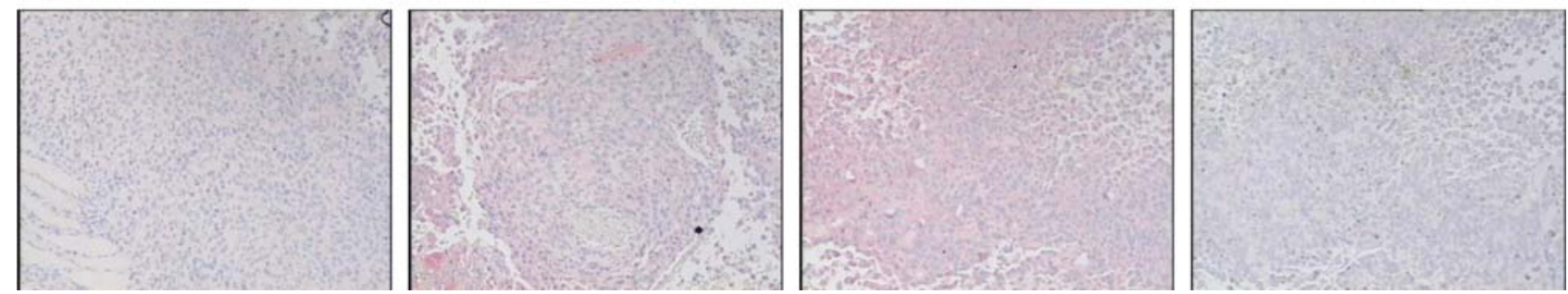

Figure 2. Vision fields from tumors with large (a) and small (b) heterogeneity of COX-2 staining 10 days after tumor implantation. (Coefficient of variation was 1.85 and 0.66 , respectively; $\mathrm{p}<0.05)$.

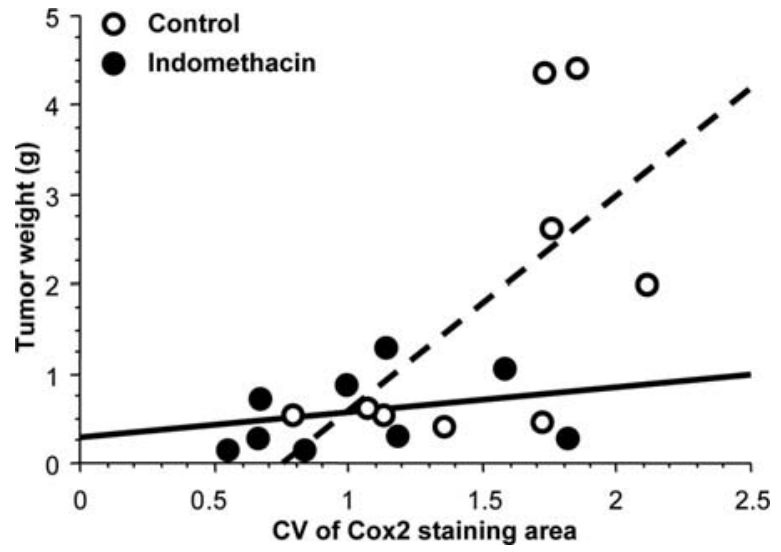

Figure 3. The relationship between the coefficient of variation of COX-2 staining area and tumor weight in indomethacin treated (10 days) and control mice (Correlation analysis by Spearman Rank correlation; $\mathrm{p}<0.03$ ).

indomethacin treatment compared to untreated controls (Fig. 4A and $\mathrm{B}, \mathrm{p}<0.05$ ). PCNA protein appeared smoothly stained in nuclei and cystoplasm from treated tumors compared to the granulated staining of control tumors.

Forward stepwise regression analysis, which involved all evaluated stained protein factors, showed that EGF-R belonged to a significantly predicting model of tumor growth in both indomethacin treated and untreated control animals (Table VI), while p21 and p27 protein predicted tumor growth in indomethacin treated mice only (Table VI). These results suggest that EGF-R signaling is a key transduction pathway related to tumor growth attenuation during indomethacin treatment in vivo. This conclusion was further supported by the observations that indomethacin treatment decreased tumor tissue transcripts of EGF-R and KRas mRNA during indomethacin treatment, although JAK1, STAT1, STAT3, cjun, ELK1 and PI3K transcripts did not show any significant
Table IV. Correlation analyses between staining area of COX-2 and growth related proteins and DNA strand breaks (TUNEL) in tumor tissue from indomethacin treated and control mice evaluated in areas with positive COX-2 staining.

\begin{tabular}{|c|c|c|c|c|c|}
\hline Protein & Treatment & $\mathrm{n}_{1}$ & $\mathrm{n}_{2}$ & Rho & p-value \\
\hline \multicolumn{6}{|l|}{ Apoptosis } \\
\hline \multirow[t]{2}{*}{ BAX } & Indomethacin & 6 & 20 & 0.30 & NS \\
\hline & Control & 6 & 35 & 0.54 & $<0.01$ \\
\hline \multirow[t]{2}{*}{ TUNEL } & Indomethacin & 7 & 26 & 0.03 & NS \\
\hline & Control & 6 & 35 & 0.58 & $<0.001$ \\
\hline \multirow[t]{2}{*}{ Bcl-2 } & Indomethacin & 7 & 26 & 0.74 & $<0.001$ \\
\hline & Control & 6 & 33 & 0.58 & $<0.01$ \\
\hline \multirow[t]{2}{*}{ c-jun } & Indomethacin & 9 & 35 & 0.47 & $<0.01$ \\
\hline & Control & 9 & 53 & 0.14 & NS \\
\hline \multicolumn{6}{|c|}{ Cell cycle and cell proliferation } \\
\hline \multirow[t]{2}{*}{$\mathrm{p} 21$} & Indomethacin & 9 & 35 & 0.35 & $<0.05$ \\
\hline & Control & 9 & 53 & 0.36 & $<0.01$ \\
\hline \multirow[t]{2}{*}{$\mathrm{p} 27$} & Indomethacin & 6 & 22 & 0.49 & $<0.05$ \\
\hline & Control & 6 & 34 & 0.10 & NS \\
\hline \multirow[t]{2}{*}{ p53 } & Indomethacin & 6 & 25 & 0.24 & NS \\
\hline & Control & 6 & 35 & 0.46 & $<0.01$ \\
\hline \multicolumn{6}{|c|}{ Metastasis/Invasion } \\
\hline \multirow[t]{2}{*}{ NM23 } & Indomethacin & 9 & 33 & 0.48 & $<0.01$ \\
\hline & Control & 9 & 50 & 0.46 & $<0.01$ \\
\hline
\end{tabular}

Spearman rank correlation analysis: $\mathrm{n}_{1}$, number of animals sacrificed 10 days after tumor implantation; $\mathrm{n}_{2}$, number of evaluated vision fields of tumor tissue; NS, not significant. 


\section{$\operatorname{coX}-2(A)$}

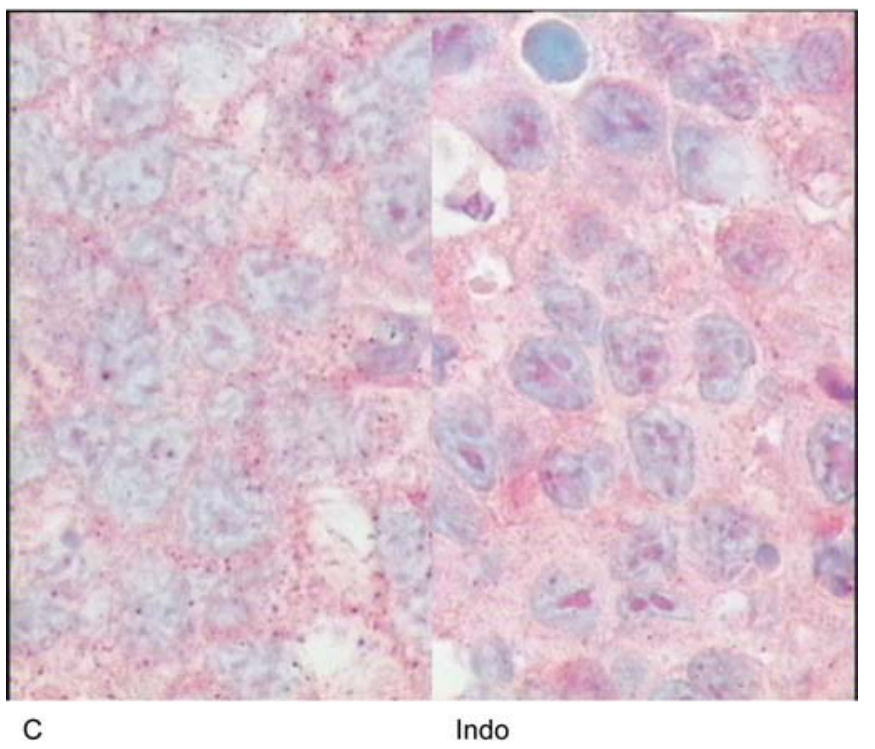

PCNA (B)

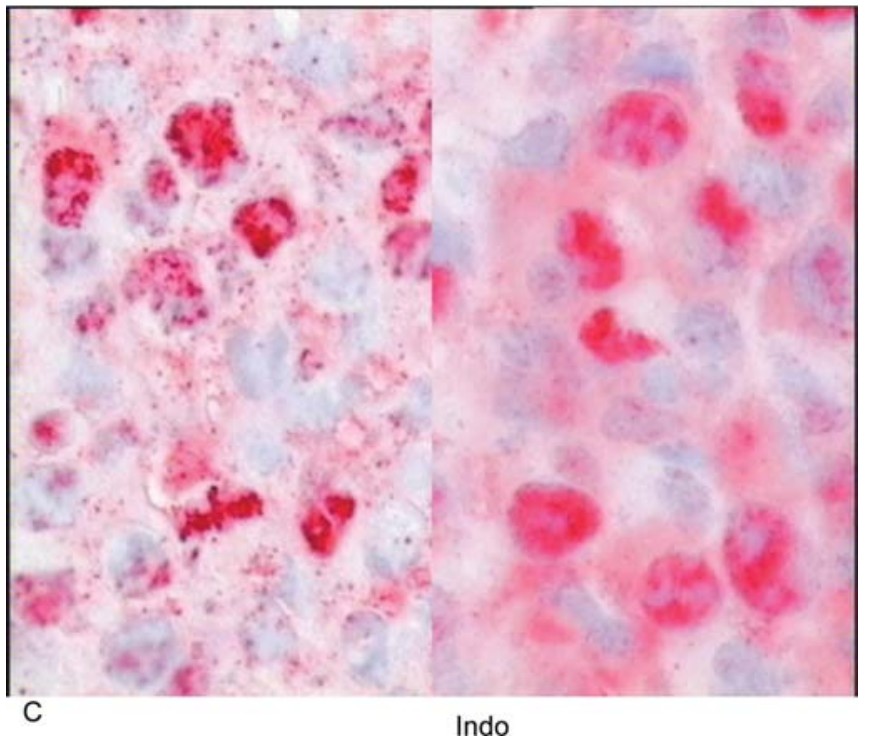

Figure 4. Altered appearance and distribution of COX-2 (A) and PCNA (B) staining in tumor tissue following 10-day growth with and without indomethacin treatment (Indo), C, controls). Positive staining is red. Background stained nuclei are blue.

difference in tumor tissue following indomethacin treatment in vivo (Table VII) (Fig. 5A and B). By contrast, MCG 101 cells displayed a pronounced loss of EGF-R mRNA when cultured in vitro for 3 days. Transcripts of KRas, PI3K, JAK1, STAT3 and c-jun were down-regulated in vitro in the presence of indomethacin while STAT1, ELK1 and GAPDH (housekeeping gene) did not show any such decline (Table VIII).

\section{Discussion}

The relationship between cancer and inflammation is well known. Virchow hypothesized as early as 1863 that origin of cancer is at sites with chronic inflammation, where much later research pointed out prostaglandins as key factors.
Table V. Correlation analyses between tumor growth (weight) and the mean staining area of various growth related proteins in tumor tissue with areas from all tumor-bearing mice at the end of experiments.

\begin{tabular}{lccc}
\hline Protein & $\mathrm{n}_{1}$ & Rho & p-value \\
\hline $\begin{array}{l}\text { Angiogenesis } \\
\quad \text { EGF-R }\end{array}$ & 13 & 0.78 & $<0.01$ \\
$\begin{array}{l}\text { Cell cycle and proliferation } \\
\quad \text { PCNA } \\
\quad \text { c-jun }\end{array}$ & 18 & -0.68 & $<0.01$ \\
$\begin{array}{l}\text { Metastasis/invasion } \\
\quad \text { NM23 }\end{array}$ & 18 & -0.63 & $<0.01$ \\
& 18 & -0.57 & $<0.05$ \\
\hline
\end{tabular}

Spearman rank correlation analysis: $\mathrm{n}_{1}$, number of animals at 10 days after tumor implantation.

Table VI. Multivariate analysis on proteins in randomly selected tumor tissue predicting tumor growth (weight) by forward stepwise regression analysis on all proteins listed in Table III and calculated separately for indomethacin treated and control mice with tumors.

\begin{tabular}{lcccc}
\hline $\begin{array}{l}\text { Treatment } \\
\text { group }\end{array}$ & Protein & $\mathrm{n}_{1}$ & $\begin{array}{c}\text { Standardized } \\
\text { coefficient }\end{array}$ & $\mathrm{p}$-value \\
\hline Control mice & EGF-R & 6 & 0.88 & $<0.02$ \\
$\begin{array}{l}\text { Indomethacin } \\
\text { treated mice }\end{array}$ & EGF-R & 7 & -0.37 & $<0.001$ \\
& $\mathrm{p} 21$ & 9 & -1.10 & $<0.001$ \\
& $\mathrm{p} 27$ & 6 & 0.27 & $<0.001$ \\
\hline $\mathrm{n}_{1}$, number of animals sacrificed 10 days after tumor implantation.
\end{tabular}

Studies around 1960 confirmed that unspecific cyclooxygenase inhibition influenced tumor net-growth, in part by reduced angiogenesis. Our own research has followed up on these observations demonstrating that COX-1/COX-2 inhibition by indomethacin, a classic unspecific cyclooxygenase inhibitor, affects local and systemic inflammation in both experimental and clinical cancer $(3,4,9,12)$. Such inhibitory effects may lead to reduced tumor growth and improved tumor-host conditions by promoting appetite and reduced catabolism in several tissues.

In experimental models, it is evident that such effects are related to altered prostanoid metabolism, particularly reduced production of $\mathrm{PGE}_{2}$, which signals through specific membrane G-protein related subtype $\mathrm{EP}_{1-4}$ receptors $(33,36)$. Similar findings are also available in human models (39). Accordingly, we observed that $\mathrm{EP}_{2}$ expression in colorectal cancer tissue predicted reduced survival in multivariate analyses following 


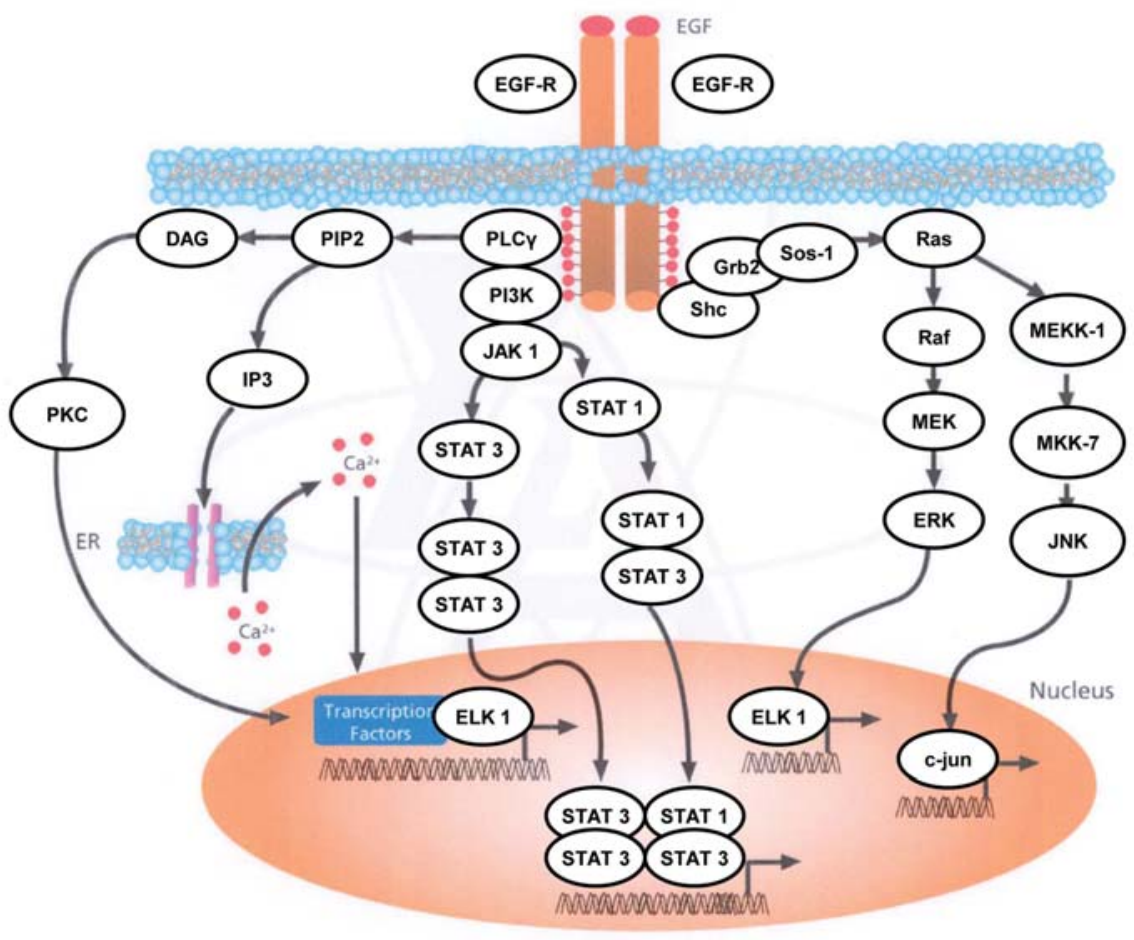

B

EGF-R ( $p<0.03)$

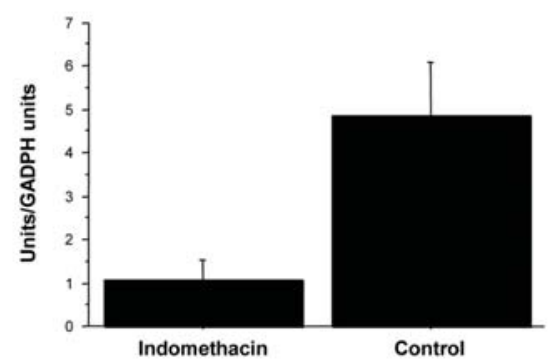

$\operatorname{KRas}(p<0.01)$

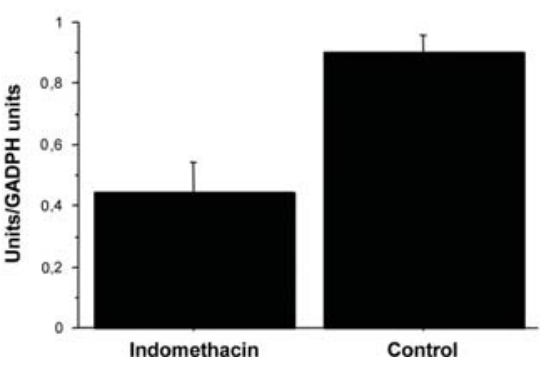

Figure 5. (A) The EGF receptor signal transduction pathway with down-stream regulators. (B) EGF-R and KRas2 mRNA transcripts in tumor tissue at 10 days of tumor growth with and without indomethacin treatment.

primary radical resections (39). Such results agree with evidence that both primary and secondary interventions with cyclooxygenase inhibitors appeared to reduce incidence and progression of colorectal cancer in various cohorts and individuals $(40,41)$. Such findings have encouraged studies on cell and tissue specimens with observations that COX-2 expression and prostanoid activity in a variety of tumors are elevated. However, sparse information exists from studies in vivo where COX-2 is usually not evenly distributed among cells in malignant tumors, although it is often claimed that COX-2 is generally up-regulated in cancer cells.

By contrast, immunohistochemical evaluations of tumor tissue usually demonstrate that COX-2 expression rather appears to be localized to certain areas within tumors, with occasionally increased expression also in normal stroma cells, as observed for RNA transcript of COX-2 in colon cancer tissue (42). Therefore, it remains unclear whether increased COX-2 expression in tumor cells is the result of true upregulation in response to certain factors or may represent a loss of suppression in such cells. Whatever the explanation, uneven appearance of COX-2 protein in tumor tissue implies tumor cell heterogeneity regarding prostanoid production $(43,44)$. Thus, it is difficult to confirm how cell signaling exerts effects among different cells in heterogeneous tumor compartments. In vitro co-cultivation of highly selected tumor and normal cells may not correctly reflect the complex in vivo conditions among stroma, endothelial cells and infiltrating inflammatory cells in proximity to proliferation of tumor cells in areas with hypoxia (45). Therefore, a main issue in the present study was to evaluate co-variations between COX-2 
Table VII. Tumor tissue transcripts downstream of the EGF receptor signal transduction pathway (Fig. 5A), at 5 and 10 days of tumor growth.

\begin{tabular}{lcccc}
\hline & $\begin{array}{c}\text { Days } \\
\text { of treatment }\end{array}$ & Indomethacin & Control & p-value \\
\hline EGF-R & $\begin{array}{c}\text { 5 days } \\
\text { 10 days }\end{array}$ & $16.0 \pm 3.0$ & $23.6 \pm 12.0$ & $\mathrm{NS}$ \\
& & $1.05 \pm 0.48$ & $4.86 \pm 1.22$ & $<0.03$ \\
K-Ras & 5 days & $0.27 \pm 0.03$ & $0.45 \pm 0.10$ & $<0.07$ \\
& 10 days & $0.42 \pm 0.11$ & $0.90 \pm 0.06$ & $<0.01$ \\
PI3K & 5 days & $0.21 \pm 0.01$ & $0.24 \pm 0.02$ & $\mathrm{NS}$ \\
JAK 1 & 5 days & $0.40 \pm 0.01$ & $0.42 \pm 0.05$ & $\mathrm{NS}$ \\
STAT 1 & 5 days & $0.47 \pm 0.10$ & $0.25 \pm 0.05$ & $\mathrm{NS}$ \\
& 10 days & $0.53 \pm 0.12$ & $1.10 \pm 0.39$ & $\mathrm{NS}$ \\
STAT 3 & 5 days & $0.49 \pm 0.05$ & $0.69 \pm 0.05$ & $\mathrm{NS}$ \\
ELK 1 & 5 days & $0.29 \pm 0.02$ & $0.28 \pm 0.03$ & $\mathrm{NS}$ \\
c-jun & 5 days & $0.21 \pm 0.03$ & $0.17 \pm 0.02$ & $\mathrm{NS}$ \\
\hline
\end{tabular}

Mean \pm SEM, units quantified by qRT PCR are normalized to GAPDH expression as the housekeeping gene; NS, not significant.

protein staining in areas of tumor cells related to the staining of defined proteins with importance for cell proliferation, apoptosis, cell adhesion, metastasis and angiogenesis $(46,47)$.

Our previous and similar attempts focused mainly on formation of micro-tumors and angiogenesis as related to cyclooxygenase inhibition $(16,48)$. Therefore, present experiments focused mainly on larger established tumors with confirmed sensitivity to cyclooxygenase metabolites for progression. This approach was chosen in order to increase the power to detect long-term relevant relationships between estimates of protein staining and tumor growth in the present model highly dependent on tissue $\mathrm{PGE}_{2}$ production. This was regarded important, since detection of alterations in protein staining is subjected to comparatively low sensitivity (49), particularly when compared to quantification of tissue content of RNA transcripts. However, transcription information is not always reflecting protein levels in cells, particularly in transformed rapidly proliferating cells with altered transporting and splicing of mRNA. Therefore, we preferred to remain with estimates of protein content by staining as major variables to allow evaluations of cellular distribution among cells, which should represent more definite information.

Despite limited sensitivity of present methodology it was clear that indomethacin provision to tumor-bearing animals altered staining areas of p53, PCNA and TGFB3 in tumor tissue. Moreover, correlation analysis between COX-2 staining and other proteins confirmed significant relationship between COX-2 and BAX, TUNEL, Bcl-2, c-jun, p21, p27, p53 and NM23. These factors are related to apoptosis, cell cycling, cell proliferation, metastasis and tumor tissue invasion.

Interestingly, EGF-R, PCNA, c-jun and NM23 also correlated to net tumor growth in univariate analyses, while forward stepwise multivariate regression analyses, indicated
Table VIII. mRNA levels in MCG 101 cells cultured with and without indomethacin in the medium for 3 days.

\begin{tabular}{lccc}
\hline & \multicolumn{2}{c}{ Cultured MCG 101 cells } & \\
\cline { 2 - 3 } & $\begin{array}{c}\text { Indomethacin } \\
(\mathrm{n}=5)\end{array}$ & $\begin{array}{c}\text { Controls } \\
(\mathrm{n}=5)\end{array}$ & $\mathrm{p}$-value \\
\hline EGF-R & $<0.01$ & $<0.01$ & - \\
K-Ras & $0.93 \pm 0.07$ & $1.66 \pm 0.15$ & $<0.003$ \\
PI3K & $0.81 \pm 0.01$ & $1.08 \pm 0.03$ & $<0.0001$ \\
JAK1 & $0.72 \pm 0.03$ & $1.00 \pm 0.06$ & $<0.004$ \\
STAT1 & $0.90 \pm 0.03$ & $1.11 \pm 0.10$ & $\mathrm{NS}$ \\
STAT3 & $0.60 \pm 0.05$ & $1.10 \pm 0.02$ & $<0.001$ \\
ELK1 & $1.36 \pm 0.09$ & $1.36 \pm 0.13$ & $\mathrm{NS}$ \\
c-jun & $0.38 \pm 0.02$ & $0.84 \pm 0.08$ & $<0.001$ \\
GAPDH & $1.12 \pm 0.01$ & $1.01 \pm 0.02$ & $<0.004$ \\
\hline
\end{tabular}

Mean \pm SEM, units quantified by qRT PCR; NS, not significant.

EGF-R a positive and negative predictor of net tumor growth in treated and untreated mice. Similarly, significant predictions were obtained from p21 and p27 following cyclooxygenase inhibition. These indications agree with several previous studies from cell culture experiments (21-31), where the EGF-R pathway was involved in prostaglandin forward and backward signaling within tumor cells, although it is not yet clear how EGF-R promotes $\mathrm{PGE}_{2}$ production and how increased $\mathrm{PGE}_{2}$ concentrations stimulate the appearance of EGF-R ligand(s) and up-regulation of EGF-R in cell cultures.

Accordingly, our qPCR analyses confirmed that EGF-R and KRas transcripts were significantly decreased in tumor tissue from indomethacin treated mice in vivo, which may subsequently influence downstream signaling implied from our in vitro estimates of RNA transcripts (Fig. 5A; Table VII). Thus, our present information suggests that tumor cell clones, with increased COX-2 expression and increased $\mathrm{PGE}_{2}$ production, may be sensitive to EGF-R inhibition particularly in combination with cyclooxygenase inhibitors of either COX-2 alone or unspecific COX-1/COX-2 inhibitors. This agrees with our recent observation that $\mathrm{COX}-1$ production parallels COX-2 induction, in clinical colon cancer tissue and is also in agreement with observations in experimental models (50). COX-2 has been reported to be present on the endoplasmic reticulum and on the outer and inner nuclear membrane as well as in the nucleoplasm of cells. Accordingly, indomethacin treated tumors displayed association of COX-2 to nucleoli, which may render the enzyme less accessible to arachidonic acid as an explanation to decreased $\mathrm{PGE}_{2}$ levels in tumor tissue $(51,52)$.

Protein staining was evaluated in a number of areas within each tumor and the coefficient of variation in staining was used as a measure of variability of protein content in tumor tissue. The variation of COX-2 staining within a tumor appeared significantly reduced by indomethacin treatment, but the overall amount of COX-2 protein staining in tumor tissue was as expected not affected by indomethacin treatment, 
although COX-2 transcripts may be at some cellular conditions (50). These results suggest that indomethacin made the tumors more homogeneous in COX-2 expression, perhaps by interruption of positive feedback ligand mechanism(s). There was also a significant correlation between the coefficient of variation of COX-2 staining and tumor weight, which confirms that large tumors were more heterogeneous in COX-2 expression than small tumors. Thus, it is likely that rapid tumor growth and progression in the present model are highly dependent on COX-2 expressing cell clones. It is also possible that tumor derived $\mathrm{PGE}_{2}$ stimulates host stroma cells to induce EGF-R and possibly other growth factors for signaling related to increased proliferation, attenuated apoptosis and increased angiogenesis (53). Thus, it should be rewarding to use unspecific $\mathrm{COX}$-inhibitors for tumor growth attenuation as confirmed (9), since substantial amounts of $\mathrm{PGE}_{2}$ are produced by host cells.

Interestingly, cultured MCG 101 cells did not seem to be dependent at all on EGF-R expression since transcript levels were close to background levels with and without indomethacin in the incubation medium. This may indicate that some factor(s) in fetal calf serum represents alternative upstream signaling to $\mathrm{PI} 3 \mathrm{~K}$, since several downstream factors were reduced by indomethacin in translation of decreased proliferation and increased apoptosis $(18,50)$. Discrepant EGF-R results in vivo vs. in vitro conditions may also imply the role of tumor stroma cells for in vivo communication as earlier indicated in our clinical studies (53).

In conclusion, the present investigation on composite tumor tissue supports previous reported findings from cell culture experiments that the EGF-R pathway communicates significant effects secondary to increased prostaglandin activity within tumor cells and probably also among cells in tumor tissue. Our findings extend previous information to include downstream transcripts of at least KRas in vivo $(24,54-58)$ and several transcription factors in vitro (Table VIII).

\section{Acknowledgements}

This study was supported in parts by grants from Assar Gabrielsson Foundation (AB Volvo), Gothenburg Medical Society, the Swedish government (LUA-ALF), Swedish Cancer Society (2014) and the Swedish Research Council (08712).

\section{References}

1. Peterson HI: Tumor angiogenesis inhibition by prostaglandin synthetase inhibitors. Anticancer Res 6: 251-253, 1986.

2. Peluffo GD, Stillitani I, Rodriguez VA, Diament MJ and Klein SM: Reduction of tumor progression and paraneoplastic syndrome development in murine lung adenocarcinoma by nonsteroidal antiinflammatory drugs. Int J Cancer 110: 825-830, 2004.

3. Gelin J, Andersson C and Lundholm K: Effects of indomethacin, cytokines, and cyclosporin $\mathrm{A}$ on tumor growth and the subsequent development of cancer cachexia. Cancer Res 51: 880-885, 1991

4. Sandstrom R, Gelin J and Lundholm K: The effect of indomethacin on food and water intake, motor activity and survival in tumour-bearing rats. Eur J Cancer 26: 811-814, 1990.

5. Meric JB, Rottey S, Olaussen K, Soria JC, Khayat D, Rixe O and Spano JP: Cyclooxygenase-2 as a target for anticancer drug development. Crit Rev Oncol Hematol 59: 51-64, 2006.

6. Brown JR and DuBois RN: Cyclooxygenase as a target in lung cancer. Clin Cancer Res 10: S4266-S4269, 2004.
7. Cahlin C, Korner A, Axelsson H, Wang W, Lundholm K and Svanberg E: Experimental cancer cachexia: the role of hostderived cytokines interleukin (IL)-6, IL-12, interferon-gamma, and tumor necrosis factor alpha evaluated in gene knockout, tumor-bearing mice on C57 Bl background and eicosanoiddependent cachexia. Cancer Res 60: 5488-5493, 2000.

8. McMillan DC, Leen E, Smith J, Sturgeon C, Preston T, Cooke TG and McArdle CS: Effect of extended ibuprofen administration on the acute phase protein response in colorectal cancer patients. Eur J Surg Oncol 21: 531-534, 1995.

9. Lundholm K, Gelin J, Hyltander A, Lonnroth C, Sandstrom R, Svaninger G, Korner U, Gulich M, Karrefors I, Norli B, Hafström L, Kewenter J, Olbe L and Lundell L: Antiinflammatory treatment may prolong survival in undernourished patients with metastatic solid tumors. Cancer Res 54: 5602-5606, 1994.

10. Cahlin C, Gelin J, Delbro D, Lonnroth C, Doi C and Lundholm K: Effect of cyclooxygenase and nitric oxide synthase inhibitors on tumor growth in mouse tumor models with and without cancer cachexia related to prostanoids. Cancer Res 60: 1742-1749, 2000.

11. Lönnroth C, Svaninger G, Gelin J, Cahlin C, Iresjö B-M, Cvetkovska E, Edström S, Andersson M, Svanberg E and Lundholm K: Effects related to indomethacin prolonged survival and decreased tumor growth in a mouse tumor model with cytokine dependent cancer cachexia. Int J Oncol 7: 1405-1413, 1995.

12. Lundholm K, Daneryd P, Korner U, Hyltander A and Bosaeus I: Evidence that long-term COX-treatment improves energy homeostasis and body composition in cancer patients with progressive cachexia. Int J Oncol 24: 505-512, 2004.

13. Limsukon A, Susanto I, Hoo GW, Dubinett SM and Batra RK: Regression of recurrent respiratory papillomatosis with celecoxib and erlotinib combination therapy. Chest 136: 924-926, 2009.

14. Wu R, Abramson AL, Shikowitz MJ, Dannenberg AJ and Steinberg BM: Epidermal growth factor-induced cyclooxygenase- 2 expression is mediated through phosphatidylinositol-3 kinase, not mitogen-activated protein/extracellular signal-regulated kinase kinase, in recurrent respiratory papillomas. Clin Cancer Res 11: 6155-6161, 2005.

15. Jalili A, Pinc A, Pieczkowski F, Karlhofer FM, Stingl G and Wagner SN: Combination of an EGFR blocker and a COX-2 inhibitor for the treatment of advanced cutaneous squamous cell carcinoma. J Dtsch Dermatol Ges 6: 1066-1069, 2008.

16. Axelsson H, Lönnroth C, Wang W, Svanberg E and Lundholm K: Cyclooxygenase inhibition in early onset of tumor growth and related angiogenesis evaluated in EP1 and EP3 knockout tumorbearing mice. Angiogenesis 8: 339-348, 2005.

17. Axelsson H, Bagge U, Lundholm K and Svanberg E: A onepiece plexiglass access chamber for subcutaneous implantation in the dorsal skin fold of the mouse. Int J Microcirc Clin Exp 17: 328-329, 1997.

18. Lönnroth C, Andersson M and Lundholm K: Indomethacin and telomerase activity in tumor growth retardation. Int J Oncol 18: 929-937, 2001

19. Rao M, Yang W, Seifalian AM and Winslet MC: Role of cyclooxygenase-2 in the angiogenesis of colorectal cancer. Int J Colorectal Dis 19: 1-11, 2004.

20. Gately S and Li WW: Multiple roles of COX-2 in tumor angiogenesis: a target for antiangiogenic therapy. Semin Oncol 31: 2-11, 2004.

21. Nishimura M, Shin MS, Singhirunnusorn P, Suzuki S, Kawanishi M, Koizumi K, Saiki I and Sakurai H: TAK1-mediated serine/threonine phosphorylation of epidermal growth factor receptor via p38/extracellular signal-regulated kinase: NF\{kappa\}B-independent survival pathways in tumor necrosis factor alpha signaling. Mol Cell Biol 29: 5529-5539, 2009.

22. Singh R, Lei P and Andreadis ST: PKC-delta binds to E-cadherin and mediates EGF-induced cell scattering. Exp Cell Res 315: 2899-2913, 2009

23. Adachi S, Shimizu M, Shirakami Y, Yamauchi J, Natsume H, Matsushima-Nishiwaki R, To S, Weinstein IB, Moriwaki H and Kozawa O: (-)-Epigallocatechin gallate downregulates EGF receptor via phosphorylation at Ser1046/1047 by p38 MAPK in colon cancer cells. Carcinogenesis 30: 1544-1552, 2009.

24. Bergmann F, Breinig M, Hopfner M, Rieker RJ, Fischer L, Kohler C, Esposito I, Kleeff J, Herpel E, Ehemann V, Friess H, Schirmacher P and Kern MA: Expression pattern and functional relevance of epidermal growth factor receptor and cyclooxygenase-2: novel chemotherapeutic targets in pancreatic endocrine tumors? Am J Gastroenterol 104: 171-181, 2009. 
25. Chen L, He Y, Huang H, Liao H and Wei W: Selective COX-2 inhibitor celecoxib combined with EGFR-TKI ZD1839 on nonsmall cell lung cancer cell lines: in vitro toxicity and mechanism study. Med Oncol 25: 161-171, 2008.

26. Gadgeel SM, Ali S, Philip PA, Ahmed F, Wozniak A and Sarkar FH: Response to dual blockade of epidermal growth factor receptor (EGFR) and cycloxygenase-2 in nonsmall cell lung cancer may be dependent on the EGFR mutational status of the tumor. Cancer 110: 2775-2784, 2007.

27. Banu N, Buda A, Chell S, Elder D, Moorghen M, Paraskeva C, Qualtrough D and Pignatelli M: Inhibition of COX-2 with NS398 decreases colon cancer cell motility through blocking epidermal growth factor receptor transactivation: possibilities for combination therapy. Cell Prolif 40: 768-779, 2007.

28. Sheng G, Guo J and Warner BW: Epidermal growth factor receptor signaling modulates apoptosis via p38alpha MAPKdependent activation of Bax in intestinal epithelial cells. Am J Physiol Gastrointest Liver Physiol 293: G599-G606, 2007.

29. Lanza-Jacoby S, Burd R, Rosato FE Jr, McGuire K, Little J, Nougbilly N and Miller S: Effect of simultaneous inhibition of epidermal growth factor receptor and cyclooxygenase- 2 in HER-2/neu-positive breast cancer. Clin Cancer Res 12: 6161-6169, 2006.

30. Huh YH, Kim SH, Kim SJ and Chun JS: Differentiation statusdependent regulation of cyclooxygenase-2 expression and prostaglandin E2 production by epidermal growth factor via mitogen-activated protein kinase in articular chondrocytes. J Biol Chem 278: 9691-9697, 2003.

31. Coffey RJ, Hawkey CJ, Damstrup L, Graves-Deal R, Daniel VC, Dempsey PJ, Chinery R, Kirkland SC, DuBois RN, Jetton TL and Morrow JD: Epidermal growth factor receptor activation induces nuclear targeting of cyclooxygenase-2, basolateral release of prostaglandins, and mitogenesis in polarizing colon cancer cells. Proc Natl Acad Sci USA 94: 657-662, 1997.

32. Chun KS and Surh YJ: Signal transduction pathways regulating cyclooxygenase-2 expression: potential molecular targets for chemoprevention. Biochem Pharmacol 68: 1089-1100, 2004

33. Breyer RM, Bagdassarian CK, Myers SA and Breyer MD: Prostanoid receptors: subtypes and signaling. Annu Rev Pharmacol Toxicol 41: 661-690, 2001

34. Brown JR and DuBois RN: COX-2: a molecular target for colorectal cancer prevention. J Clin Oncol 23: 2840-2855, 2005.

35. Clevers H: Colon cancer - understanding how NSAIDs work. N Engl J Med 354: 761-763, 2006.

36. Sugimoto Y, Narumiya S and Ichikawa A: Distribution and function of prostanoid receptors: studies from knockout mice. Prog Lipid Res 39: 289-314, 2000.

37. Lundholm K, Edstrom S, Ekman L, Karlberg I, Bylund AC and Schersten T: A comparative study of the influence of malignant tumor on host metabolism in mice and man: evaluation of an experimental model. Cancer 42: 453-461, 1978.

38. Karlberg I, Edstrom S, Ekman L, Johansson S, Schersten T and Lundholm K: Metabolic host reaction in response to the proliferation of nonmalignant cells versus malignant cells in vivo. Cancer Res 41: 4154-4161, 1981.

39. Gustafsson A, Hansson E, Kressner U, Nordgren S, Andersson M, Wang W, Lonnroth C and Lundholm K: EP(1-4) subtype, COX and PPARgamma receptor expression in colorectal cancer in prediction of disease-specific mortality. Int J Cancer 121: 232-240, 2007.

40. Auman JT, Church R, Lee SY, Watson MA, Fleshman JW and McLeod HL: Celecoxib pre-treatment in human colorectal adenocarcinoma patients is associated with gene expression alterations suggestive of diminished cellular proliferation. Eur J Cancer 44: 1754-1760, 2008.

41. Chan AT, Ogino S and Fuchs CS: Aspirin use and survival after diagnosis of colorectal cancer. JAMA 302: 649-658, 2009.

42. Gustafsson A, Hansson E, Kressner U, Nordgren S, Andersson M, Lonnroth $\mathrm{C}$ and Lundholm K: Prostanoid receptor expression in colorectal cancer related to tumor stage, differentiation and progression. Acta Oncol 46: 1107-1112, 2007.
43. Sano H, Kawahito Y, Wilder RL, Hashiramoto A, Mukai S, Asai K, Kimura S, Kato H, Kondo M and Hla T: Expression of cyclooxygenase-1 and -2 in human colorectal cancer. Cancer Res 55: 3785-3789, 1995

44. Adegboyega PA, Ololade O, Saada J, Mifflin R, Di Mari JF and Powell DW: Subepithelial myofibroblasts express cyclooxygenase-2 in colorectal tubular adenomas. Clin Cancer Res 10: 5870-5879, 2004.

45. Lönnroth C, Andersson M, Arvidsson A, Nordgren S, Brevinge H, Lagerstedt $\mathrm{K}$ and Lundholm K: Preoperative treatment with a non-steroidal antiinflammaatory drug (NSAID) increases tumor tissue infiltration of seemingly activated immune cells in colorectal cancer. Cancer Immun 8: 5, 2008.

46. Eisinger AL, Prescott SM, Jones DA and Stafforini DM: The role of cyclooxygenase- 2 and prostaglandins in colon cancer. Prostaglandins Other Lipid Mediat 82: 147-154, 2007.

47. Negishi M, Sugimoto Y and Ichikawa A: Molecular mechanisms of diverse actions of prostanoid receptors. Biochim Biophys Acta 1259: 109-119, 1995.

48. Axelsson H, Lönnroth C, Andersson M, Wang W and Lundholm K: Global tumor RNA expression in early establishment of experimental tumor growth and related angiogenesis following COX-inhibition evaluated by microarray analysis. Cancer Inform 2: 199-213, 2007.

49. Garewal H, Ramsey L, Fass R, Hart NK, Payne CM, Bernstein H and Bernstein C: Perils of immunohistochemistry: variability in staining specificity of commercially available COX-2 antibodies on human colon tissue. Dig Dis Sci 48: 197-202, 2003.

50. Gustafsson A, Andersson M, Lagerstedt K, Lönnroth C, Nordgren S and Lundholm K: Receptor and enzyme expression for prostanoid metabolism in colorectal cancer as related to tumor tissue $\mathrm{PGE}_{2}$. Int J Oncol 36: 469-478, 2010.

51. Spencer AG, Woods JW, Arakawa T, Singer, II and Smith WL: Subcellular localization of prostaglandin endoperoxide $\mathrm{H}$ synthases- 1 and -2 by immunoelectron microscopy. J Biol Chem 273: 9886-9893, 1998.

52. Vazquez-Tello A, Fan L, Hou X, Joyal JS, Mancini JA, Quiniou C, Clyman RI, Gobeil F Jr, Varma DR and Chemtob S: Intracellularspecific colocalization of prostaglandin E2 synthases and cyclooxygenases in the brain. Am J Physiol Regul Integr Comp Physiol 287: R1155-R1163, 2004.

53. Cahlin C, Lönnroth C, Arvidsson A, Nordgren S and Lundholm K: Growth associated proteins in tumor cells and stroma related to disease progression of colon cancer accounting for tumor tissue $\mathrm{PGE}_{2}$ content. Int J Oncol 32: 909-918, 2008.

54. Zhang X, Chen ZG, Choe MS, Lin Y, Sun SY, Wieand HS, Shin HJ, Chen A, Khuri FR and Shin DM: Tumor growth inhibition by simultaneously blocking epidermal growth factor receptor and cyclooxygenase- 2 in a xenograft model. Clin Cancer Res 11: 6261-6269, 2005.

55. Jin $\mathrm{Y}$, Zhang $\mathrm{C}$, Zeng $\mathrm{W}$, Taya $\mathrm{K}$ and Tan TQ: Interactive actions of prostaglandin and epidermal growth factor to enhance proliferation of granulosa cells from chicken prehierarchical follicles. Prostaglandins Other Lipid Mediat 83: 285-294, 2007.

56. Buchanan FG, Holla V, Katkuri S, Matta P and DuBois RN: Targeting cyclooxygenase-2 and the epidermal growth factor receptor for the prevention and treatment of intestinal cancer. Cancer Res 67: 9380-9388, 2007.

57. Selvendiran K, Bratasz A, Tong L, Ignarro LJ and Kuppusamy P: NCX-4016, a nitro-derivative of aspirin, inhibits EGFR and STAT3 signaling and modulates Bcl-2 proteins in cisplatinresistant human ovarian cancer cells and xenografts. Cell Cycle 7: 81-88, 2008.

58. Yano T, Zissel G, Muller-Qernheim J, Jae Shin S, Satoh H and Ichikawa T: Prostaglandin E2 reinforces the activation of Ras signal pathway in lung adenocarcinoma cells via EP3. FEBS Lett 518: 154-158, 2002. 